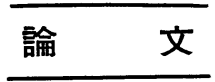

\title{
円すい孔内面の相互反射と色ずれ
}

\author{
正会員福井 和久海*

\section{Interflection and Color Shift in the Conical Cavities} \\ Wakumi Fukui (Member) \\ (Himeji Institute of Technology)
}

\begin{abstract}
In the preceding report, the author mentioned the interflection and color shift in the multiple Vshaped grooves. And in this paper, he calculates the shape factors in the conical cavities which are concave and have self interflection, dividing their surfaces into 40 parts in all and 80 at most when the gradient is steep.

And, analytically he traces the effective reflectances and the color shifts to compare with the experimental results.

As a result, shape factors in the conical cavities are found to be quite similar to those of multiple V-shaped grooves if their angles of the apex are equal. These approximate values of shape factors between them can explain quite well the similarity of spectral reflectance curves, of chromaticities and of other experimental results.

But, in the conical cavities, difference between the analytical and the experimental results is less than that in the multiple V-shaped grooves. Such results are due to the better surface condition of the specimens made of plaster and to their comparatively larger size which could make the formation better.
\end{abstract}

\section{1. 緒言}

前回の報告1)では, $\mathrm{V}$ 型溝内面汇拈汓る相互反射と色 ずれについて実験值と理論值とを比較して検討したが， 続いて, 円すい孔の場合についても同様な比較を試み た.

この実験は,さきの V 型溝の実験と同じく, California 大学の O'Brien 教授研究室で行なったものである が233)，その理論的検討飞必要な円すい孔内面の Shape Factor の計算にかなりの時間をとられ，まとめるのが 遅れた.

もっとも，電子計算機が自由に駆使できれば，所要時 間をきわめて短縮できたのであったが，費用とか使用時 間の割当てなどで使用が思らにまかせず，わずか一部分 の計算を処理するのにとどまった。

しかし，円すい孔では，V型溝の場合よりもすべての 点でよい結果が得られたので，ここにその概要を報告す る.

* 姬路工業大学

\section{2. 試料および実験方法}

まず，真ちゅうで頂角が $60^{\circ}, 30^{\circ}, 15^{\circ}$ の円すいをつ くり,これを型作りするようと組み合わせた木わくの中 に入れ，この中に水に溶いたプラスターを流し込んで, 固まってから取りはずして，頂角 $\theta$ が $60^{\circ}, 30^{\circ}, 15^{\circ}$ の円すい孔をるつ試料を作った。また，別に標準となる 平面板 $\left(\theta=180^{\circ}\right)$ および, 後には, 頂角が $120^{\circ}$ のもの を作って一部の実験に供した。

その大きさは，

$$
\begin{aligned}
& \theta=60^{\circ} \ldots \ldots \ldots 42.9 \times 42.9 \times 38.1\left(\mathrm{~mm}^{3}\right) \\
& \theta=30^{\circ} \ldots \ldots \ldots . .42 .9 \times 42.9 \times 63.5\left(\mathrm{~mm}^{3}\right) \\
& \theta=15^{\circ} \ldots \ldots \ldots . .42 .9 \times 42.9 \times 101.6\left(\mathrm{~mm}^{3}\right)
\end{aligned}
$$

表面に打㚈る円すい孔の直径は $23.8 \mathrm{~mm}$ である.

こうして素地の試料ができると,プライマーを吹き付 け，次いで不透明払散性塗料を塗布した。その種類は次 のようである。

青色塗料……....Pittsburgh Paints, 5-9-19

黄色塗料……...Pittsburgh Paints, Yellow, 11-2 


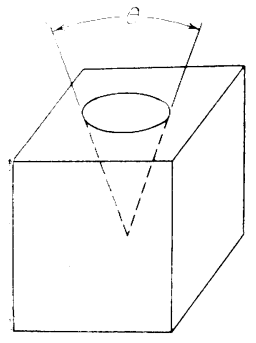

第 1 図

円すい孔試料

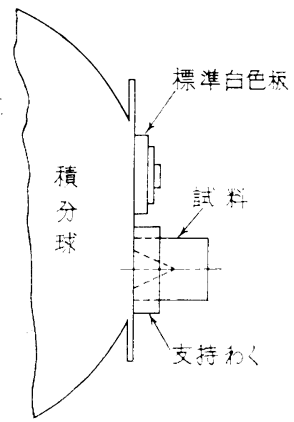

第 2 図

試料の取り付け位圈
赤柴色塗料……Tempera, Megenta

これらの試料の外観は第 1 図のようである.

測定は, 前の V 型溝の場合之同様で, GE 製の自記分 光光度計の测定部に試料を第 2 図のよらに取り付けて 行なった。このとき,試料をできるだけ多くするために, 素地のもの，プライマーを吹き付けたもの，および塗料 を塗布したものと，試料作成の 各段階で順次に 測定し た.

\section{3. 測 定 結 果}

測定の結果, 得られた分光反射率曲線を図示すると, 第 3，4，5，6，7 図の破線群および $\theta=180^{\circ}$ の実線の ようになる。

これらの曲線から色度および反射率を計算し，また， $\theta=180^{\circ}$ の曲線を基準にして $\theta=60^{\circ}, 30^{\circ}, 15^{\circ}$ のとき の理論的な分光反射率曲線（実線）と，それらに基づく 色度計算を行なった。

このらち, 黄色の試料に限り, $\theta=120^{\circ}$ のものを作っ て測定したから，その結果もあわせて記入している.

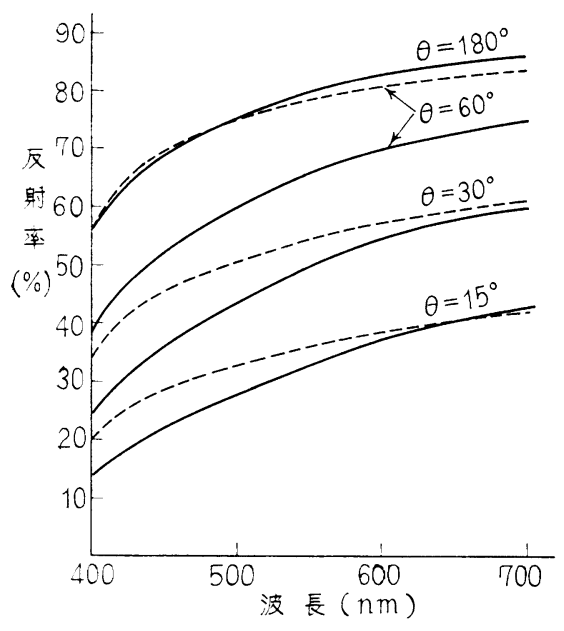

第 3 図 プラスター円すい孔の分光反射率曲線 一計算值 $\quad \cdots . . .$. 測定值
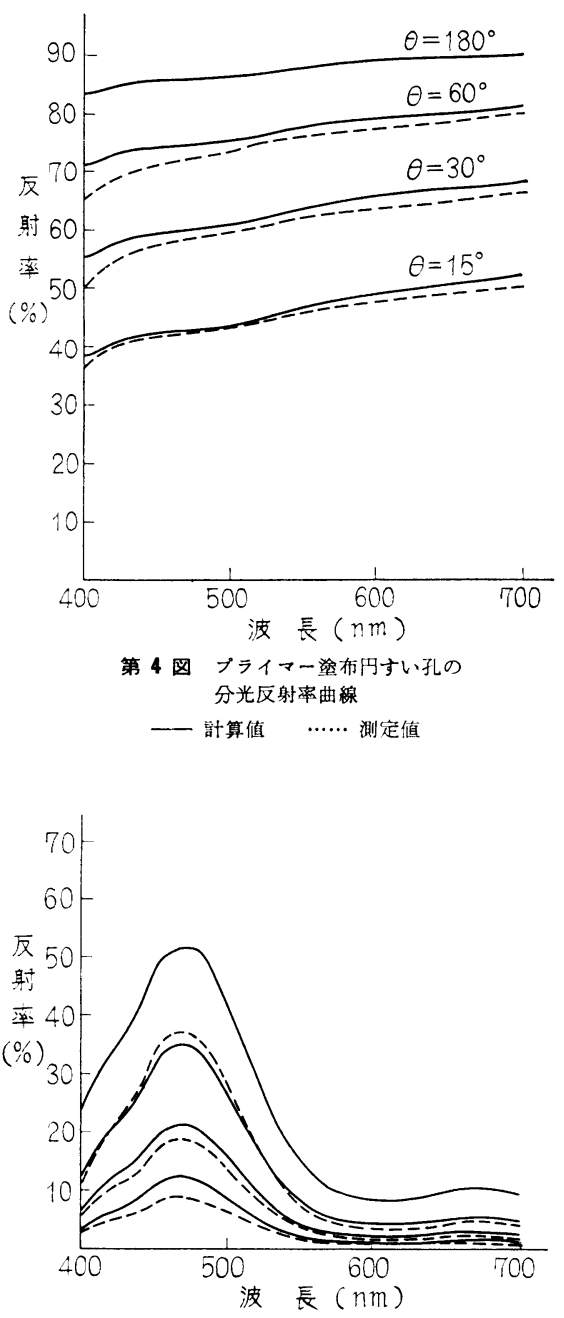

第 5 図 青色円すい孔の分光反射率曲線 — 計算值 $\quad$ ……测定値

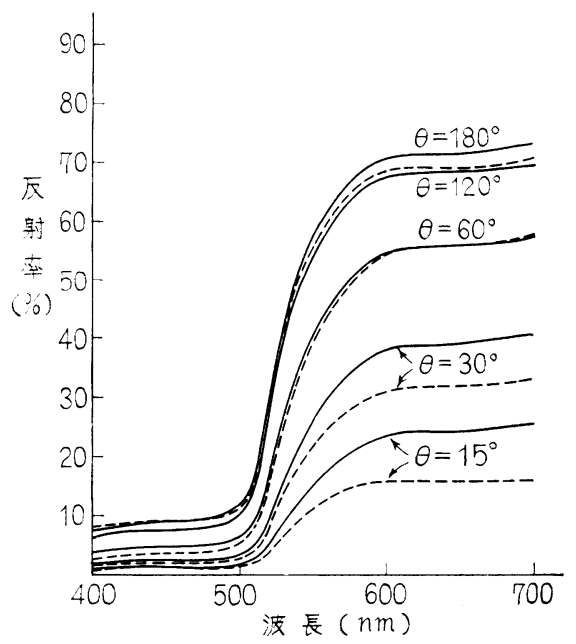

第 6 图 黄色円すい孔の分光反射率曲線 一䂥算值 $\quad \cdots . .$. 测定值 


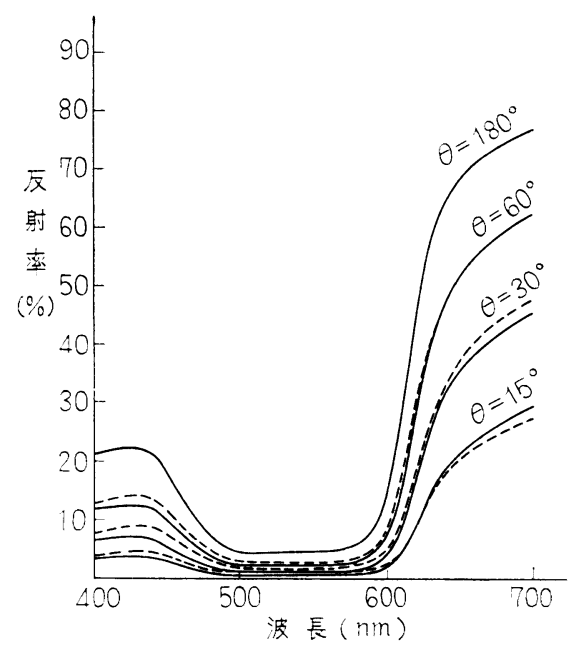

第 7 图赤紫色円正孔の分光反射率曲線 一計算值 $\quad \cdots . .$. 测定值

\section{4. 相 互 反射}

\section{1 円すい孔内の Shape Factor}

相互反射系を取り扱うには, 各面の相刘的位置関係に よって決まる係数, Shape Factor を導入して多元連立 一次方程式, あるいはマトリックスをつくり計算を進め る方法がとられている.したがって,ここでもまず円す

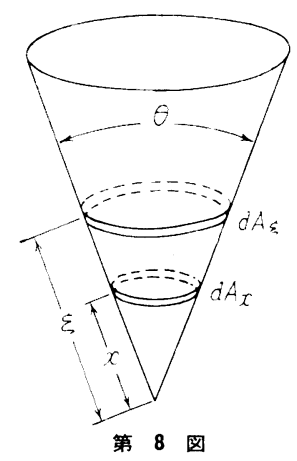

い孔内の Shape Factorを 求めなければならない。

こ礼まで, 円すい孔内の Shape Factor は泶を用い て近似計算をする程度であ ったが，最近(1)式が報告さ れた4).

すなわち,第 8 図にお いて，頂点から $x$ 执よび の距離にある雀面上の微少 面積をそれぞれ $d A_{x}, d A_{\text {ई }}$ とし，その間の Shape Factor を $F(x, \xi)$ とすると, (1)式が得られる.

$$
\begin{aligned}
& d F(x, \xi)=\frac{\cos ^{2}\left(\frac{\theta}{2}\right)}{2 x \sin \left(\frac{\theta}{2}\right)} \\
& \times\left\{1-|\xi-x| \frac{(\xi-x)^{2}+6 \xi x \sin ^{2}\left(\frac{\theta}{2}\right)}{\left[(\xi-x)^{2}+4 \xi x \sin ^{2}\left(\frac{\theta}{2}\right)\right]^{3}}\right\}
\end{aligned}
$$

この式を整頓して次のようにする.

$$
d F(x, \xi)=\alpha(\theta) \cdot \beta(x, \xi) d \xi
$$

ただし，

$$
\begin{aligned}
\alpha(\theta) & =\frac{\cos ^{2}\left(\frac{\theta}{2}\right)}{2 \cdot \sin \left(\frac{\theta}{2}\right)} \\
\beta(x, \xi) & =\frac{1}{x}\left\{1-|\xi-x| \frac{(\xi-x)^{2}+6 \xi x \sin ^{2}\left(\frac{\theta}{2}\right)}{\left[(\xi-x)^{2}+4 \xi x \sin ^{2}\left(\frac{\theta}{2}\right)\right]^{\frac{3}{2}}}\right\}
\end{aligned}
$$

さて, 実験は $\theta=60^{\circ}, 30^{\circ}, 15^{\circ}$ で行なったから， $\alpha(\theta)$ は一定の数值となり， $\beta(x, \xi)$ を計算すればよい，しか し,この式の中には $|\xi-x|$ の項があって, $x=\xi$ の点 で不連続になるうえ積分が困難なので，不連続となる点 の両側で別々ヒンンプソンの法則を用いて総和を求め た。

そのための分割は， $x, \xi$ 共 40 等分, 変化の大きい之 ころでは 80 等分である.

この計算を, 円すい孔全体にわたって分割した各点で 行ならとかなり時間がかかるので，実際には円すいを軸 に直角な平面で 10 分割し，この分割された面相互間の Shape Factor を求めるち法をとり，上述の分割でこれ ら Shape Factor の約半数を求め, 残りのものは相反 法則を用いて算出した5).

このとき, 分割された面の面積を求めることが必要と なるが，このよらに分割された円すいの各部分は，円寸 いまたは円すい台となるので, これらを切断, 展開して 羿形，あるいはそれらの差として容易に計算することが できる.

電子計算機を用いるとき汇は，ブログラムを組みさ兄 すれば，以上述べたすべての計算をきうかて短時間比す ませることができるのであるが，ここでは，つごうによ り $\beta(x, \xi)$ の計算の一部を NEAC 203 を用いて計算し たのにとどまった。

\section{2 相互反射の計算}

相互反射系を構成する $n$ 個の完全执散面が平面で䇆る 場合には，自己以外の他の面との関倸をみればよかった が，円すい孔のように山面になると，自己要素自体内で の相互反射が存在するため，これに基づく項を加觉る。

その一般的な式は，(2)式のようになる2).

$$
\begin{aligned}
& L_{i}=L_{0 i}+\rho_{i} F(i, i) L_{i}+\rho_{i} \sum_{\substack{j=1 \\
(j \neq i)}}^{n} F(i, j) L_{j} \\
& =L_{0 i}+\rho_{i} \sum_{j=1}^{n} F(i, j) L_{j}
\end{aligned}
$$

ただし， $i=1,2,3$

ここに, $L_{0 i}$ : 面 $i$ の初期光束発散度, $L_{i}$ : 面 $i$ の相 互反射後の光束発散度, $\rho_{i}$ : 面 $i$ の反射率, $F(i, i)$ : Self Shape Factor, $F(i, j)$ : Shape Factor である.

この実験で，測定に使用した円すい孔試料，標準平面 板などの反射特性は，いずれも付録のところで述べてい 
るように完全执散性からずれ, また, 分光光度けで为単 色光が武料に垂直に入射してはいない,しかし, 上記の 相互反射の式を簡単にするため，次のように仮定して計 算を進めた。すなわち,

(1) 円寺い孔の中心軸に, 平行な光が孔の表面に一様 に入射する.

(2) 円すい孔内面は, 全体にわたって完全拉散性であ る.

(3) 円すい孔浣全な円すい状で亦る。

第 9 図において, $A_{0}:$ 门 寸い孔の開口值の淔積, $F(\mathrm{c}, \mathrm{c})$ ：円すい孔内面の Self Shape Factor, $F(0, \mathrm{c})$ : 円劣い孔の開口面之円す い孔内面との間の Shape Factor, $L_{0}$ : 単位面皘当た りの入射光束, $L_{c}$ : 归すい 孔内面で相互伩射した後の 光束発散度, $o_{\lambda}$ : 分光反射 站とする, 内面の初期光 束発散度 $L_{0 c}$, 全人射光束

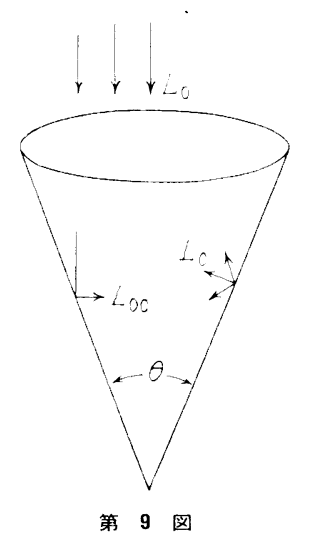

おょび全射出光東㳄の上うになる。

$$
L_{0 c}=o_{i} L_{0} \sin \left(\frac{\theta}{2}\right)
$$

(全入射光束) $=A_{0} L_{0}$

(全射出光束) $=A_{0} L_{c} F(0, \mathrm{c})$

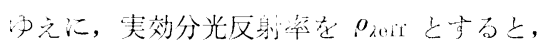

$$
\begin{aligned}
o_{\text {ieff }} & =\frac{(\text { 全射出光束 })}{(\text { 全入射光束 })}=\frac{A_{0} L_{c} F(0, \mathrm{c})}{A_{0} L_{0}} \\
& =\frac{L_{c} F(0, \mathrm{c})}{L_{0}} \ldots \ldots \ldots \ldots \ldots \ldots \ldots \ldots \ldots \ldots \ldots \ldots \ldots \ldots \ldots
\end{aligned}
$$

しかし, 坷多い孔认面之, その開口面とは閉曲面をな 古から,

$$
F(0, \mathrm{c})=1
$$

また，(2)式から，

$$
L_{c}=L_{0 c}+\rho_{i} L_{c} F(\mathrm{c}, \mathrm{c})
$$

(3), 4), (5), 6)式方，

$$
o_{\lambda \mathrm{eff}}=\frac{\sigma_{\lambda} \sin \left(\frac{\theta}{2}\right)}{1-o_{\lambda} \cdot F(\mathrm{c}, \mathrm{c})}
$$

ここで，分光反斯率 $\sigma_{\lambda}$ にかえて反射㻭 $o$ を用いる 之,

$$
\rho_{\mathrm{efr}}=\frac{\rho \sin \left(\frac{\theta}{2}\right)}{1-\rho \cdot F(\mathrm{c}, \mathrm{c})}
$$

ただし，

$$
o=\frac{\int_{\lambda_{1}}^{\lambda_{2}} o_{i} P_{i} \bar{y}_{\lambda} d \lambda}{\int_{\lambda_{1}}^{\lambda_{2}} P_{i} \bar{y}_{\lambda} d \lambda}
$$

$P_{\lambda}$ : 分光エネルギー分布 $\bar{y}_{\lambda}$ : スペリトル刺激值 各出の平面の武料が亦す分光反射被曲緗を基にして, (7)式から $\theta=60^{\circ}, 30^{\circ}, 15^{\circ}$ の場合の分光反射率を計算 し，それを图亦したものが前揭の第 $3 ， 4 ， 5 ， 6 ， 7$ 図の奏線である。このうち, 黄色の試料には $\theta=120^{\circ}$ の 場合の結果もあわせて記入してある。

次に， $(7),(8)$ 式加分光及射率 $\rho_{\lambda}$ 之效分光反射率

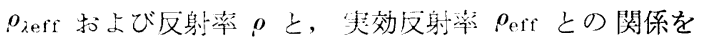
$\theta=180^{\circ}, 60^{\circ}, 30^{\circ}, 15^{\circ}$ の各場合について計算し, 測 定值と比較すると第 10，11，12図が得られる。

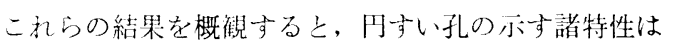
$\mathrm{V}$ 型溝のそれらと似てはいるが, 測定值がよりよく理論 值に近ついていることがわかる。

また，丧面の状態から双ると兴地ではずれが大きい

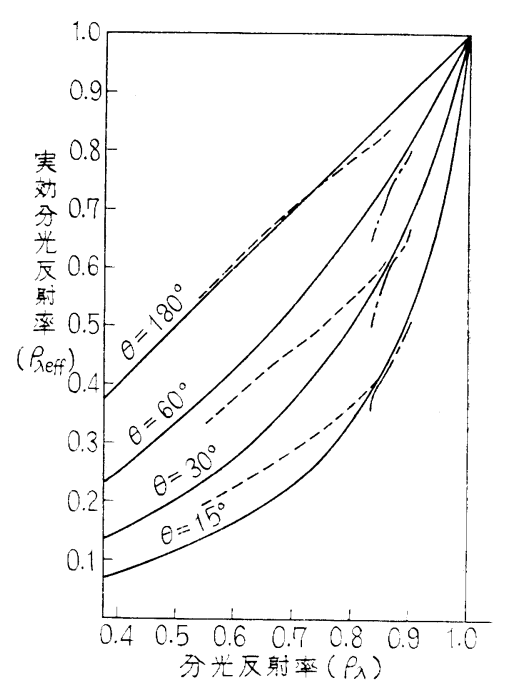

第 10 図相互反射による丰效分光反 射率の変化

- 胡算倠 …… プラスター円すい孔

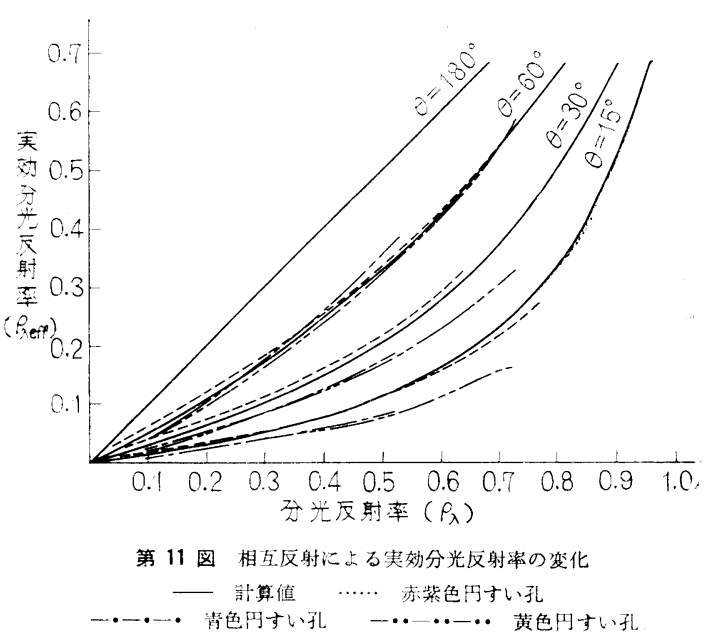

Vol. 50 No. 6 


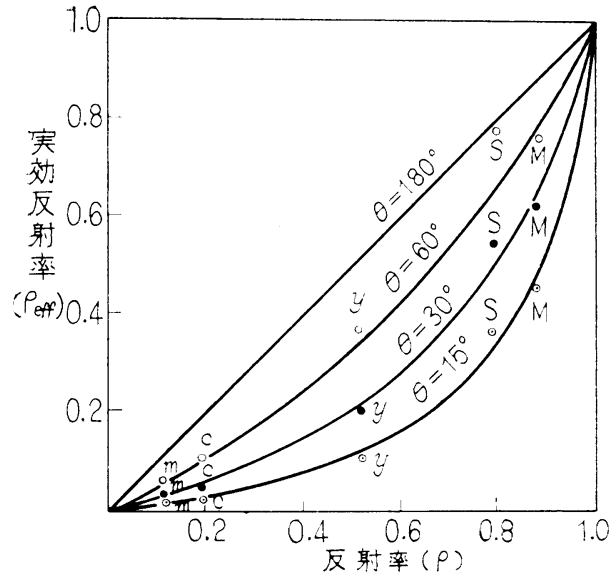

第 12 図 相互反射に上る実効反射率の变化 一計算值 $\bigcirc: \theta=60^{\circ}$ 测定値 $\bigcirc: \theta=30^{\circ}$ 测定値 $\bigcirc: \theta=15^{\circ}$ 测定值 $\mathrm{S}:$ プシスター円す い孔 $\mathrm{M}$ ：ブライマー慾布円すい孔 $\mathrm{y}$ : 黄色円 すい孔 $\mathrm{c}$ ：青色円すい孔 $\mathrm{m}$ : 赤紫色円すい孔

が，透明プライマーおよび不透明抎散性塗料を吹き付け るとかなり理論值に近ついてきている，角度でみると $\theta=60^{\circ}$ のものがよく, $\theta=15^{\circ}$ のもので比較的ずれが大 きい。

\section{5. 色ずれ}

すでに述べた分光反射率曲線から，C光源を基準とし て CIE の測色值, $x, y$ を求め, さらに, $u, v$ に換 算してその結果を図示すると，第 13，14，15，16 図と なる。

またC光源の色度点から, これらの色度点をスペクト ル色軌跡, および純紫軌跡に平行な線上に投影して, 測 定值が理論值からずれる様子を叕ると，第 17，18，19，

20，21，22図のようになる。

これらの結果をまとめると，次のよらにいえる.

（1）理論值からのずれの方向黄色の試料では大体 主波長で短くなる方向へ, 赤紫色, 青色の試料では主波 長で長くなる方向へずれている，てして素地のものおよ びプライマーを吹き付けた試料が示すよらに，スペクト ル色軌跡上 $540 \sim 570 \mathrm{~nm}$ の範井で，これら二つの相反 する傾向が混合している.

（2）理論值からのずれの大きさ 黄色, 赤紫色, 青 色の試料では, 大体 $\theta=15^{\circ}$ のずれが最大, $\theta=60^{\circ}$ の それが最小であるが，素地のもの，プライマーを吹き付 けたものでは少し様子が違っている.これも前述のよら に，二つの方向の相異なる色ずれがこの付近で合するも のと考えると説明できる.

その他黄色の試料では， $\theta=120^{\circ}$ の色度点が，また素 地の試料では, $\theta=60^{\circ}$ の色度点が平面の色度点から光

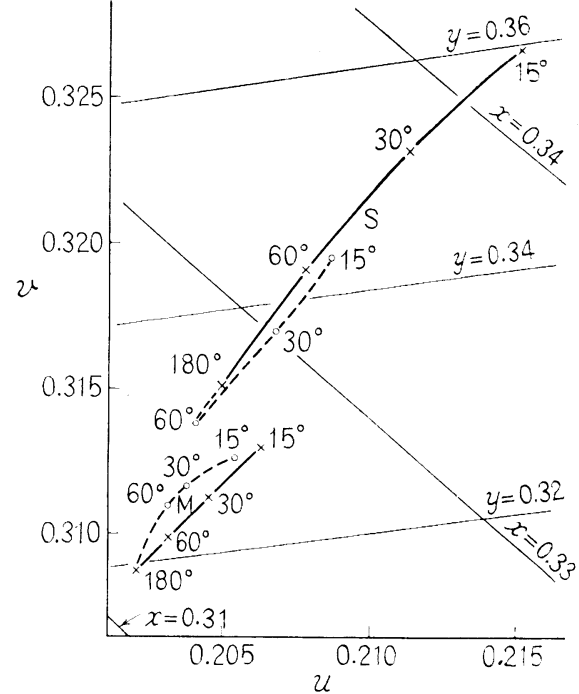

第 13 图 プラスター（S）およびブライマー 整布(M) 队すい孔の色すれ

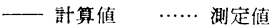

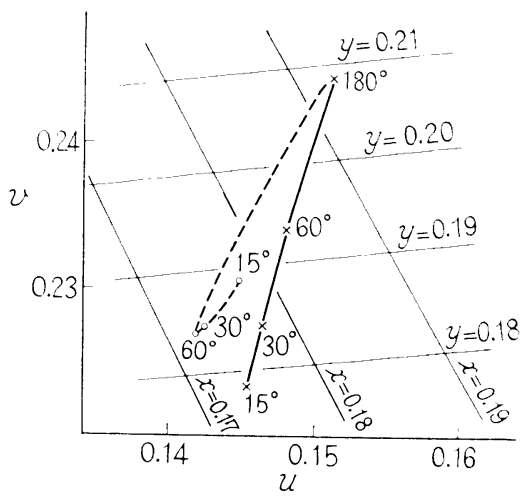

第 14 図 青色円すい孔の色すれ … 部算值 $\quad \cdots . . .$. 判定做

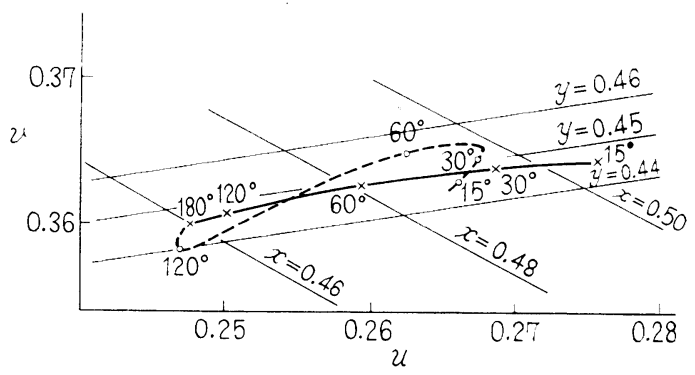

第 15 図 黄色円すい孔の色寺れ

—計算值 $\quad \cdots . .$. 測定值

源の方にずれている，この結果，相互反射が始まると 色度はあたかも一度光源の力向へずれ，相互反射が大き くなると方向を変えて主波長方向へずれるかのような現 象を示すようになっている.このよらな傾向は，V型溝 

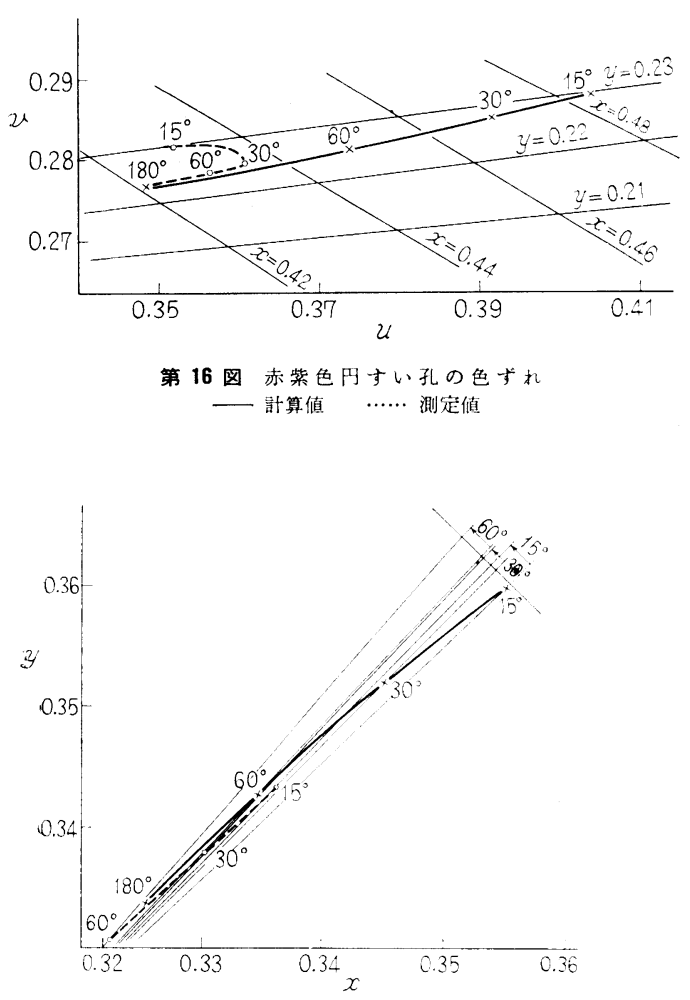

第 17 図 ブラスター円すい孔の色度の計算値 と测定値とのすれ — 計算值 $\quad \cdots . . .$. 測定值

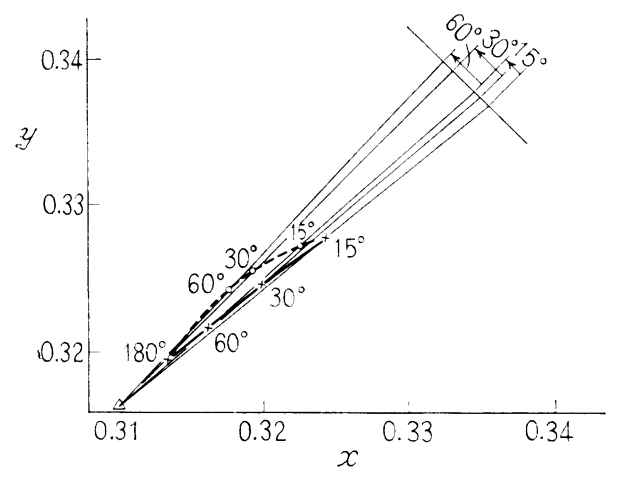

第 18 图プライマー塗布円すい孔の色度の計 算値と测定值とのずれ

一計算値 $\quad \cdots . . .$. 測定値

の場合にはみられなかったが，円すい孔の実験で現われ ている.

以上の結果をみると，やはり円すい孔に扑ける色ずれ と, V型溝の色ずれとは傾向においては等しいが，前者 のほうがより理論值に近づいてるといえる.

この理由は, 両者の Shape Factor が近似している こと，また共に反射特性が完全抾散性からずれている

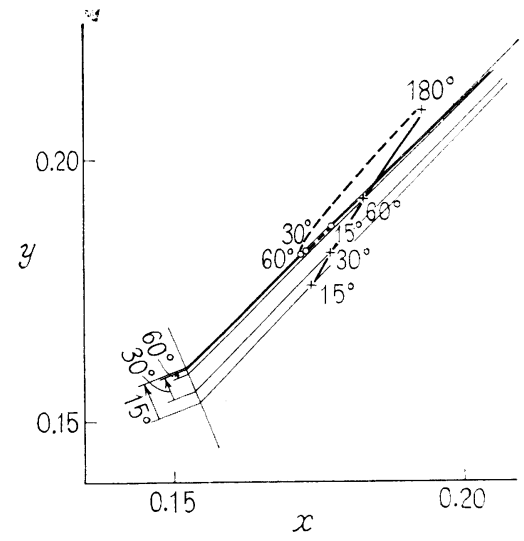

第 19 図青色队すい孔の色度の計算值と测定 值とのずれ —計算值 $\quad$ ……測定维

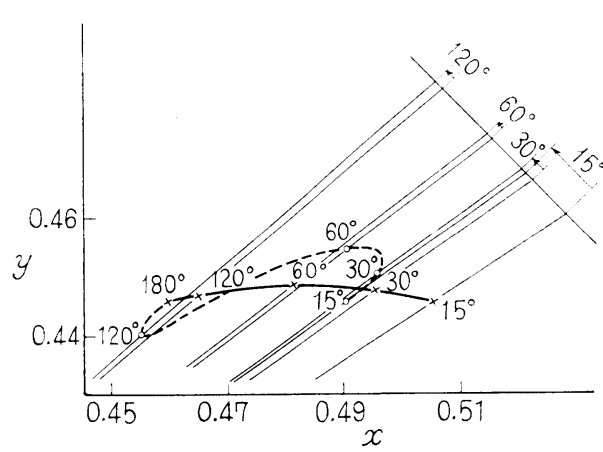

第 20 図 黄色円すい孔の色度の計算值と测定 值とのずれ 一 計算値 $\quad \cdots . .$. 测定値

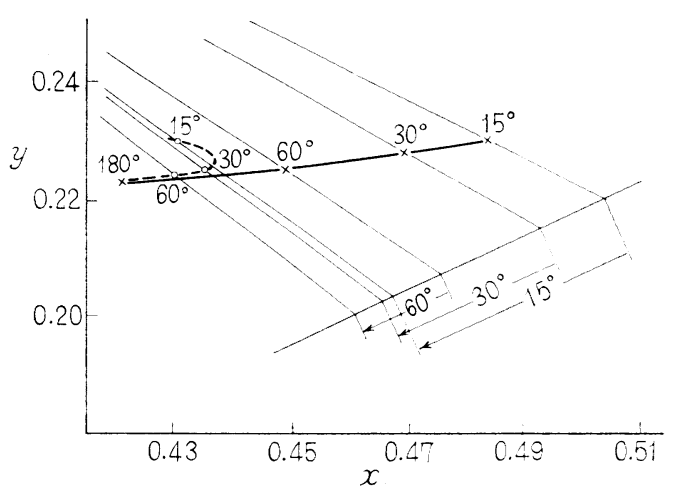

第 21 図赤紫色円すい孔の色度の計算值と測 定値とのずれ 部算值 測定値

が，円すい孔のほらがV型溝よりよい反射特性を示すこ となどに基づくものであると思われる.

（3）相互反射と色ずれ 円すい孔に执いても，相互 反射に基づく色ずれは，大体主波長方向に起こることが 明白であるが, Monochroic Color Shift および Dichroic 
Color Shift \& V 型溝の場合と同様にみられる.

ことに，测定値と理論值とが近ついたため，Dichroic Color Shift が赤紫色試料はもちろん, 黄色試料の実験 結果にまでみられるよらになっている.

目でこれら円すい孔試料を観察すると，その色ずれも さることながら，明度の低下がことに大きく影響してい るように思われた，前のV型溝の黄色試料では, 溝が深 くなると黄色のちらつきが感じられたが，円すい孔では そのような現象はなかった。試料が一つの孔をもつ単純 な形であるため, 多くの溝のある場合にみられるような 複雑な現象は起こらなかったのであろら.

\section{6. 考 察}

\section{1 試料表面の完全拡散性からのずれ}

付録にみられるように,ブラスターで型作りした試料 は，アルミニウムのような金属で作ったものよりかなり よい㹡散性をもっている。この上にブライマ一および不

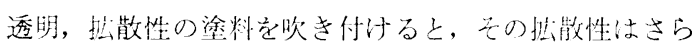
に改善されるが，どうしても完全昖散性からはずれる。

こうした表面状態は，当然測定に䛊差をもたらす。

\section{2 試料の取り付け位置}

$\mathrm{GE}$ 分光光度計で測定のとき, 試料の開口面は標準队 色板之同じ相対位置にあったが，頂点の位置は，頂角が $60^{\circ}, 30^{\circ}, 15^{\circ}$ となるのに応じて, 約 20.6,44.4, $90.4 \mathrm{~mm} こ の$ 位置からずれていた。 ゆ兑に, ここから 起こる測定䛊差は, 頂角の小さいもの汪ど大きくなって くる.

この円すい孔の頂点のずれの大きさをV 型溝の場合の ずれ $4.1,8.9,18.2 \mathrm{~mm}$ に比較すると，かなり大きい といえる。それにもかかわらず, 测定結果の理論値から のず机は心くなっている。これは, 円すい孔ではこの 測定哭差によるものが主であり，V型溝では，この䛊差 よりも他の原因に基づく呮差が大きくきいたからではあ るまいか。

\section{3 試 料 の 変 形}

円与い孔試料の形は単純であり，また比較的大きいの で型作りによる形のひずみや，個々の差異は概して少な いと思方れるが，塗料を吹き付けるとそのさらとともに 頂点が曲面状になるのは避けられないことであった。

ことに， $\theta=15^{\circ}$ の円すい孔では頂点が深いので, こ こまで塗料の吹き付汁が困難で, かなりのむらが起こっ た。こらした変形や不均一な表面状態は䛊差をもたらし ていることであろう。

以上述べた諸原因のために䛊差は避けられずここに 示したような結果となったが, 全般的にみると, 前回の $\mathrm{V}$ 型海の測定結果が，かなり理論值からずれていたのに 対して, 円すい孔ではより理論値に近いものが得られ,
実験の妥当性が認められるように思われる。

\section{7. 結言}

この報告では，さきに述べた V 型溝の場合と同様に， まず，相互反射にあずかる内面全体の Shape Factor を 計算し、これをもとにして諸結果の検討を試みたもので ある。

しかし, さらに考察をすすめると, V 型溝, 円すい孔 内面の各部分は，その位置によってそれぞれ異なった状 態にあること，たとえば，頂点付近と開口部付近とで は, 史効反射湺拈よび色ずれの様子の違っていることが 考えられる。

このため, 次回にはV 型溝, 円すい孔の内面を分割し て分割された面相互間の Shape Factor を求め, この值 を用いてさらに計算をすすめる。てして, ここで得られ た計算結果から，测定結果およびこれまでの計算の再検 討を行なら子定である。

終わりに、この実験を行ならにあたって，ご指導くだ さった O’Brien 教授ならびにご援助くださった大学院 学生諸君と職員のかたがたに感謝するとともに, 後にこ の問題を理論的に処理する際に, 文献の照会, 複写など でお世話いただいた電気試験所大阪支所の納谷博上，お よび電子計算機のブログラミングでご指示を仰いだ本学 の勝詁博士にあわせて感謝の意を表します。

\section{参 考 文 献}

(1) 袖井：照学竞 49 (昭40) 558

(2) 袖井：昭 40 電気四学会連大 (1282)

(3) 福井：姬路工大研究報告 17A（昭39） 99

(4) E.M. Sparrow, V.K. Jonsson : JOSA 53 (1963) 816

(5) 福井・小路：姬路厂大研究報告 $\mathbf{1 8 A}$ (昭40) 13

(6) 佐土根・森田 - 猪野原 : 照学誌 49 (昭40) 4

\section{付 録}

\section{円すい孔および $\mathbf{V}$ 型清の反射特性}

これまでの報告で述べた円すい孔およびV型溝の試 料は筆者の手もとにないので，その反射特性を测定する ことはできないがこのような試料の反射特性を調べる ために類似のものを作り, 素地の場合, 黄色光沢性塗 料, 黄色拉散性塗料を塗った場合について测定を行なっ た. 測定のつごう上, 光の入射角は平面では, $45^{\circ}$, $\theta=60^{\circ}$ のものでは $30^{\circ}, \theta=30^{\circ}$ のものでは $15^{\circ}, \theta=15^{\circ}$

のものでは $0^{\circ}$ とした。

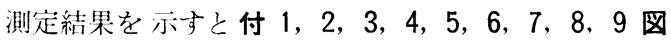
となる。

素地および光沢性塗料の束のでは, 平面 $\left(\theta=180^{\circ}\right)$ 


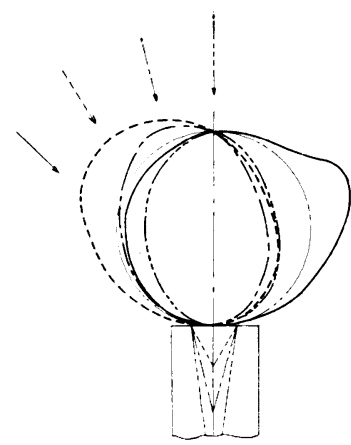

付 1 图石整円すい乱の 反射特性

- 平面 $\left(\theta=180^{\circ}\right)$

… $\theta=60^{\circ}$

-... $\theta=30^{\circ}$

- …… $\theta=15^{\circ}$

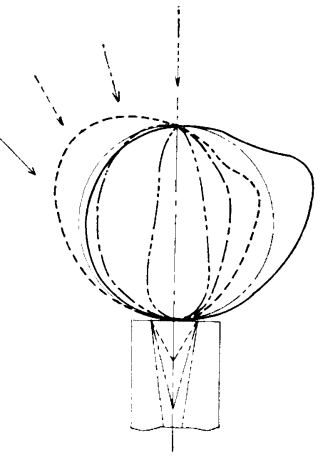

付 2 图黄色光沢性染料 を䤠布した円方 い光の反射特性

— 平面 $\left(\theta=180^{\circ}\right)$

…. $\theta=60^{\circ}$

-.... $\theta=30^{\circ}$

$\theta=15^{\circ}$

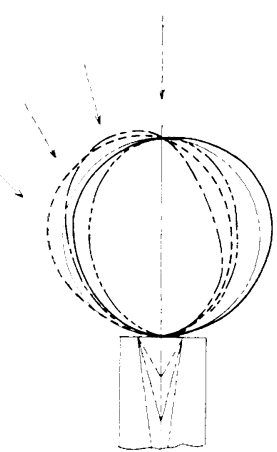

付 3 図黄色詓散性塗料 を筑布した円す い孔の反射特出$$
\left(\theta=180^{\circ}\right)
$$

( $\left.\theta=180^{\circ}\right)$

-... $\theta=30^{\circ}$

$-\cdots-\cdots \theta=15^{\circ}$

$$
+\cdots \cdots+\cdots=15^{\circ}
$$

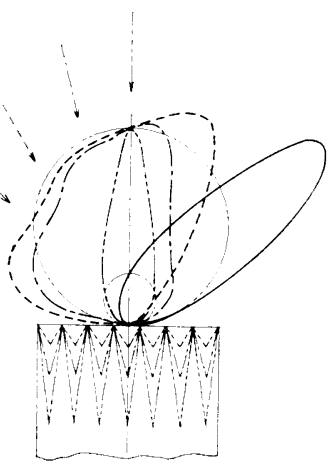

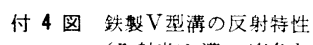
方向から)

— 平面 $\left(\theta=180^{\circ}\right)$

…. $\theta=60^{\circ}$

-.- $\theta=30^{\circ}$

-....... $\theta=15^{\circ}$ (入射光は满江值角店

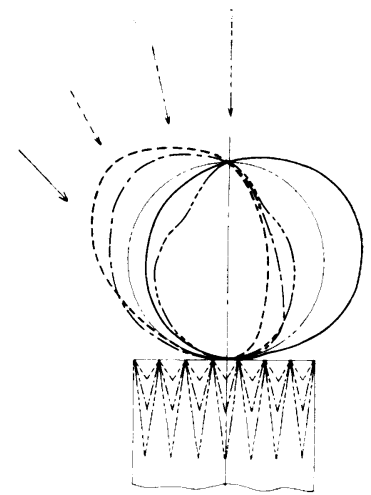

付 6 図黄色払散性滁料を叙布した V型㩐の反射特性（入射光 は㩐に直角な方向から

… 平面 $\left(\theta=180^{\circ}\right)$

…. $\theta=60^{\circ}$

$$
\text { - } \theta=30^{\circ}
$$

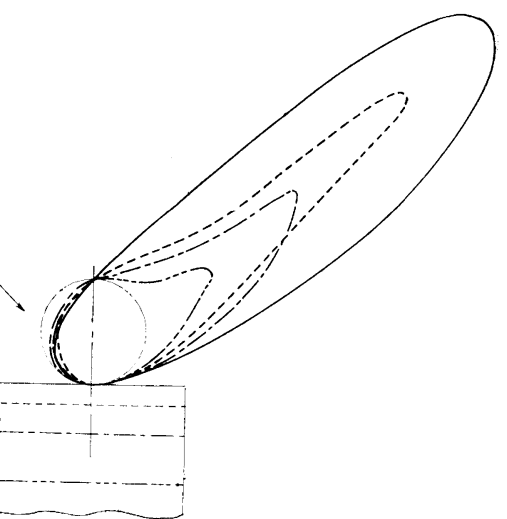

付 7 図 鉄慗V型溝の反射特性（入 射光は溝に平行な方向から

— 平面 $\left(\theta=180^{\circ}\right)$

…. $\theta=60^{\circ}$

-... $\theta=30^{\circ}$

$-\cdots-\cdots \theta=15^{\circ}$

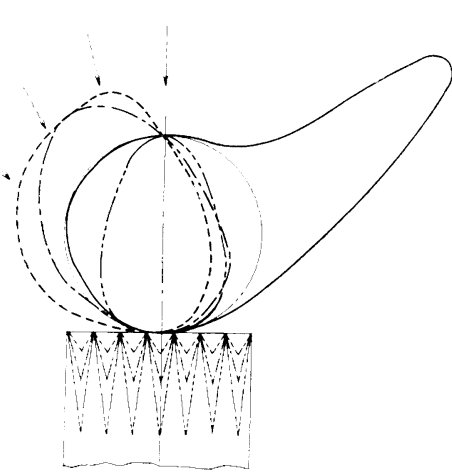

付 5 图黄色光沢性塗料を叙布した

$\mathrm{V}$ 型溝の反射特性（入射光

は满に直角な方向から

一平面 $\left(\theta=180^{\circ}\right)$

… $\theta=60^{\circ}-\cdots \cdot \theta=30^{\circ}$

$\theta=15^{\circ}$

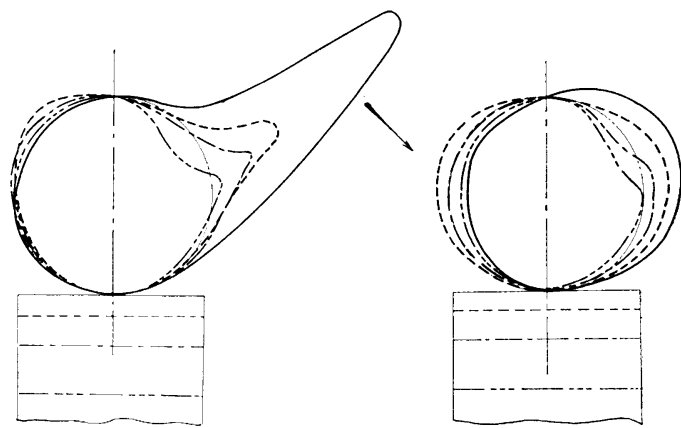

付 8 図黄色光沢性酒料を染 布したV型溝の反射 特性 (入射光は溝に 平行な力向から)

- 平面 $\left(\theta=180^{\circ}\right)$

… $\theta=60^{\circ}$

-.-. $\theta=30^{\circ}$

-....... $\theta=15^{\circ}$
付 9 図 黄色抁散性塗料を 塗布したV型溝の 反射特性（入射光 は湮比行な方向 から)

( 平面

…. $\theta=60^{\circ}$ -.-. $\theta=30^{\circ}$ 
の場合, 完全抁散性からのずれが最大であるが, 抎散性 塗料のものでは， $\theta=15^{\circ}$ のときずれが大きくなってい る.

概して円すい孔のほうがV型溝よりもすぐれた抬散性 を示している. また $\mathrm{V}$ 型溝のとき, 溝の陵線に平行な方 向から光を投射する場合には，これに直角な方向からの
場合よりも，素地のもので正反射分が著しくなってい る.

このような反射特性は, これまで述べた諸結果に相応 じているから，実験に使用した試料の反射特性も大体， このようなものであったとい党るであろう.

（受付 1966 年 1 月 22 日 再受付 1966 年 4 月 22 日） 